\title{
Comparative study of alpha amylase pro- ducing mutated and unmutated Bacillus strains by taking cost effective measures
}

\author{
Irsa Ramzan, Afeefa Chaudhry, Hamid Bashir*, Muhammad Bilal and \\ Aleena Sumrin \\ Center for Applied Molecular Biology, 87-West canal Bank Road, University of the Punjab, Lahore-53700-Pakistan \\ *Corresponding author's email: hamid.camb@pu.edu.pk \\ Citation \\ Irsa Ramzan, Afeefa Chaudhry, Hamid Bashir*, Muhammad Bilal and Aleena Sumrin. Comparative study of alpha \\ amylase producing mutated and unmutated Ba-cillus strains by taking cost effective measures. Pure and Applied \\ Biology. Vol. 8, Issue 2, pp1789-1800. http://dx.doi.org/10.19045/bspab.2019.80122
}

\begin{tabular}{llll}
\hline \hline Received: 22/03/2019 & Revised: 20/06/2019 & Accepted: 27/06/2019 & Online First: 29/06/2019 \\
\hline
\end{tabular}

\section{Abstract}

Bacillus species is considered as most appropriate bacterial specie for extracellular production of alpha amylase at commercial level. The alpha amylase is in high demand in a lot of food, beverage, and textile industries. In recent years, researchers have made many attempts to scale up the production of alpha amylase by using various strategies. The current study deals with the isolation, identification of Bacillus species and evaluation of their alpha amylase activity by random mutagenesis. Amylase producing bacteria were isolated from soil sample and further categorized via 16S rRNA technique. Random mutagenesis technique (MNNG and UV radiation) was employed to enhance the production of an enzyme. Mutants were then assessed for alpha amylase production via solid state fermentation using different agro-industrial waste, i.e. potato peels, apple peels, banana peels, wheat bran and rice husk. Different parameters such as incubation temperature, incubation period and $\mathrm{pH}$ were optimized to obtain maximum yield. Optimum amylase production $(207.84 \mathrm{U} / \mathrm{ml})$ was obtained after 48 hours of incubation at $37^{\circ} \mathrm{C}$ by using $\mathrm{MNNG}$ mutant and potato peels. This study reveals that Bacillus cereus has the potential of alpha amylase production. It further suggests that secretion of alpha amylase can further be maximized by improving the strain genetically and optimizing the fermentation conditions.

Keywords: Alpha amylase; Bacillus; MNNG; 16S rRNA; UV radiation

\section{Introduction}

Alpha amylase (endo-1,4-a-D-glucan glucohydrolase) is a secretory enzyme responsible for the cleavage of 1,4-a-D-glucosidic bonds that link the glucose molecules in a linear amylase chain [1]. This enzyme, contributes to approximately $25 \%$ of the global enzyme market owing to its significant utilization in food, textile, brewing, paper and pulp industries [2]. Alpha amylase can be isolated from animals, plants and microorganisms [3]. Microorganisms have become the organism of choice for amylase production due to advantages like high availability, ease of handling and manipulation, cheap nutrient requirement and favorable growth conditions over other production methods [1, 4]. Several Bacillus species like B. stearothermophilus [5], B. subtilis [6], B. licheniformis [7] and B. amyloliquefaciens [8] are renowned 
alpha amylase producers, and have been exploited widely due to their rapid growth rates, their capability to secrete prolific amount of proteins and general handling safety [9-11]. Several mutation studies have been carried out to achieve higher production of the enzyme as compared to the wild bacterial strains [12-14]. Many researches are now being carried out to cut the cost and time for enzyme production. Utilization of agro-industrial waste as substrates in solid state fermentation offers an alternative value-addition process for alpha amylase production $[15,16]$. A number of wastes like coffee waste [16], gram husk, mustard oilseed cake, wheat bran, and rice bran [10] have been utilized as substrates in this respect. This study investigates the effect of UV and MNNG induced mutation in Bacillus cerus on the $\alpha$-amylase production. Moreover, the current work studies the effect of potato peel, apple peel, wheat bran , banana peel, and rice husk as a substrates in case of alpha amylase production by using the mutant strains.

\section{Materials and methods}

\section{Sample collection, isolation and screening} of bacterial isolates

Soil samples of various origins were collected from starchy fields of Lahore, Pakistan. Alpha amylase producing bacteria were screened from the local soil habitat by plating the samples on Luria Bertani agar containing starch as a source of substrate [1719]. One gram of the soil sample was added in $10 \mathrm{ml}$ of sterilized distilled water, followed by shaking and incubation $15 \mathrm{~min}$ at $80^{\circ} \mathrm{C}$. $50 \mu \mathrm{l}$ from above sample was then plated on the agar medium supplemented with starch. Afterwards, the plates were incubated for 48 hours at $37^{\circ} \mathrm{C}$. Positive colonies formed clear zones of substrate degradation in the region of them were selected and stored for further processing.

\section{Morphological identification of bacterial isolates}

Morphological identification, gram staining, endospore staining, motility test and biochemical test of isolated bacteria were performed in a similar way as mentioned in "Bergey's manual of systemic bacteriology(2004) [20].

\section{Molecular characterization}

Molecular characterization of isolates showing maximum amylolytic prospective was performed with the 16S rRNA primers technique [21] for the further confirmation bacterial strains. From fresh bacterial culture the genomic DNA was extracted, according to the method described by [22, 23]. For amplification of the 16S rRNA region, universal primers were used and confirm the sequence by sequencing the product.

\section{Culture improvement by chemical mutagenesis}

Overnight grown culture of Bacillus species was treated with MNNG. The stock solution of MNNG was prepared as $7.5 \mathrm{mg} / \mathrm{ml} .1 \mathrm{ml}$ of the bacterial cells were shifted to twelve sterile eppendorf tubes. Two of them were taken as control while the remaining tubes were treated with different concentrations $(7 \mu 1,14 \mu \mathrm{l}, 21 \mu \mathrm{l}, 28 \mu \mathrm{l}$ and $35 \mu \mathrm{l})$ of MNNG from stock. Incubation was done at $37^{\circ} \mathrm{C}$ for 1 and 2 hours, respectively, followed by centrifugation at $13000 \mathrm{rpm}$ for $7 \mathrm{~min}$. The cell pellet was resuspended in $1 \mathrm{ml} \mathrm{LB}$ media and centrifuged at 13000 RPM for $7 \mathrm{~min}$. This step was repeated twice, followed by resuspension of cells in LB media.

\section{UV mutagenesis}

UV chamber was used to carry out mutations using the method adopted by [24, 25]. Vegetative culture of Bacillus cereus was centrifuged at $8000 \mathrm{rpm}$ for $10 \mathrm{~min}$. The supernatant was discarded and cell pellet was resuspended in autoclaved phosphate buffer saline $\mathrm{pH}$ : 7. Resuspended cell solution (10ml) was then exposed to UV irradiation for 30-90 minutes with constant interval of 
10min. $0.2 \mathrm{ml}$ of the irradiated culture was spread on starch agar plates. The plates were subjected to incubation at $37^{\circ} \mathrm{C}$ for $24-48 \mathrm{~h}$.

\section{Screening of mutants}

Colonies that showed largest starch hydrolysis zones were selected from UV and MNNG treated culture and were named as BCU1 and BCM1 respectively. These two colonies were preserved further for fermentation studies.

\section{Vegetative inoculum preparation}

LB (Luria-Bertani) medium was prepared using Tryptone $1 \%, \mathrm{NaCl} 0.5 \%$, and yeast extract $0.5 \%$ in Erlenmeyer flasks of $250 \mathrm{ml}$ adjusted the $\mathrm{pH} 7.0$ and autoclave the media. Culture from the fresh slants of BCU1, BCM1 and wild strains of Bacillus subtilis was inoculate in the media and Incubated in shaking incubator at $37^{\circ} \mathrm{C}$ for 18 hours, at 200RMP.

\section{Solid-state fermentation}

Optimization of amylase enzyme production was carried out using solid state fermentation in $250 \mathrm{ml}$ Erlenmeyer flask. In this study five different fermentation media were prepared using agro-industrial wastes such as apple peel, banana peel, potato peel, rice husk and wheat bran. Following fermentation media $(\mathrm{g} / \mathrm{l})$ were evaluated alpha amylase for production: M1: Apple peel, $\mathrm{Na}_{2} \mathrm{HPO}_{4}(18 \mathrm{~g} / \mathrm{L}), \mathrm{KH}_{2} \mathrm{PO}_{4}(9 \mathrm{~g} / \mathrm{L}), \quad \mathrm{NaCl}$ $(1.5 \mathrm{~g} / \mathrm{L}), \mathrm{NH}_{4} \mathrm{Cl}(3 \mathrm{~g} / \mathrm{L}) \mathrm{M} 2$ : Banana peel, $\mathrm{Na}_{2} \mathrm{HPO}_{4}(18 \mathrm{~g} / \mathrm{L}), \mathrm{KH}_{2} \mathrm{PO}_{4}(9 \mathrm{~g} / \mathrm{L}), \quad \mathrm{NaCl}$ $(1.5 \mathrm{~g} / \mathrm{L}), \mathrm{NH}_{4} \mathrm{Cl}(3 \mathrm{~g} / \mathrm{L}) \mathrm{M} 3$ : Potato peels, $\mathrm{Na}_{2} \mathrm{HPO}_{4}(18 \mathrm{~g} / \mathrm{L}), \mathrm{KH}_{2} \mathrm{PO}_{4}(9 \mathrm{~g} / \mathrm{L}), \mathrm{NaCl}$ $(1.5 \mathrm{~g} / \mathrm{L}), \quad \mathrm{NH}_{4} \mathrm{Cl}(3 \mathrm{~g} / \mathrm{L})$ M4: Rice husk, $\mathrm{Na}_{2} \mathrm{HPO}_{4}(18 \mathrm{~g} / \mathrm{L}), \mathrm{KH}_{2} \mathrm{PO}_{4}(9 \mathrm{~g} / \mathrm{L}), \quad \mathrm{NaCl}$ $(1.5 \mathrm{~g} / \mathrm{L}), \mathrm{NH}_{4} \mathrm{Cl}(3 \mathrm{~g} / \mathrm{L}) \mathrm{M} 5:$ Wheat bran, $\mathrm{Na}_{2} \mathrm{HPO}_{4}(18 \mathrm{~g} / \mathrm{L}), \mathrm{KH}_{2} \mathrm{PO}_{4}(9 \mathrm{~g} / \mathrm{L}), \mathrm{NaCl}$ $(1.5 \mathrm{~g} / \mathrm{L}), \mathrm{NH}_{4} \mathrm{Cl}(3 \mathrm{~g} / \mathrm{L}) .1 \%(\mathrm{v} / \mathrm{v})$ vegetative culture of BCU1, BCM1 and wild strains of Bacillus was inoculated in each fermentation medium under aseptic conditions. All the cultures were incubated in shaking incubator at $37^{\circ} \mathrm{C}$ for 18 hours, at 200RMP. After in- cubation supernatant of the culture was used to observe the of alpha amylase production.

\section{Enzyme assay}

The activity of amylase was determined by the method described [26]. 500 $\mu$ l of $20 \mathrm{mM}$ phosphate buffer ( $\mathrm{pH}: 6.0)$ along with $1 \%$ starch solution was added to $500 \mu \mathrm{l}$ of enzyme solution. The tubes were incubated at $37^{\circ} \mathrm{C}$ for $30 \mathrm{~min} .0 .5 \mathrm{ml}$ of DNS reagent was added to $500 \mu \mathrm{l}$ of the reaction mixture in order to stop the reaction. The tubes were again incubated in water bath at $100^{\circ} \mathrm{C}$ for 5 minutes. $4 \mathrm{ml}$ of water was added in each tube. Amount of reducing sugar produced was calculated to measure the absorbance at $540 \mathrm{~nm}$, with reference to the glucose standard. Assays were performed in triplicate and average values of all assays were reported. "One unit (U) of amylase is described as the amount of enzyme that releases $1 \mu \mathrm{mol}$ of glucose as reducing sugar per minute under the assay conditions."

\section{Results and discussion \\ Isolation, identification and screening of amylase producer}

Selection of an appropriate strain is imperative for enhanced production of alpha amylase. In current research work soil samples were obtained from diverse starchy fields of Lahore. Screening of potent strains was done by spotting them on nutrient starch medium and the diameter of starch hydrolysis zones was measured that were formed around the colonies. Isolates showing a large zone of hydrolysis were selected for further study. Morphological and biochemical characteristics of the isolate are summarized in (Table 1).

\section{Molecular characterization}

In this study, 10 isolates were selected for sequencing with16S RNA to validate their molecular properties. To confirm the exact sequence blast all the sequence results in the gene databank with BLASTN2 software. Among the selected isolates, the isolate with the highest zone of hydrolysis shows a simi- 
larity index of $94 \%$ with Bacillus cereus strain A65 (sequence ID: gi|1114444182|KX057546.1), and thus used further in mutation and fermentation studies. While the other isolates that were selected for $16 \mathrm{~S}$ sequencing based on their hydrolytic activity against starch were found to be different strains of Bacillus subtilis. The sequencing results revealed that isolate with the highest zone of hydrolysis was the member of the genus Bacillus. The reason behind it might be due to highly prevalent these bacillus species in soil samples [27]. Anto et al. Also reported that Bacillus cereus has the ability to produce alpha amylase [28].

\section{Mutagenesis}

Amylase is a commercially valuable enzyme which is used in a lot of industrial processes. Mutations are thus induced to hyper activate the enzyme production in bacteria. Studies have proved that mutations not only increase the rate of cell growth, but they also augment the enzyme production ability of bacte- ria [29]. In this study maximum zone of hydrolysis with MNNG treatment was obtained when cells of bacterial strain Bacillus cereus strain A65 were treated with $7 \mu 1$ of MNNG for 2hours.In (Table $2 \&$ Figure 1) represents the zone of hydrolysis shown by the MNNG mutants. When Bacillus cereus A65 was exposed to UV treatment from 30 to 90 minutes, highest zone was observed in a culture that was treated for 80 min shown in (Table 3 \& Figure 2). After that, growth of culture decreases drastically along with reduction in starch hydrolysis shown in (Figure 2: plate 7, 8 \& 9). Both the UV and MNNG mutant strain show a considerable amount of increase in starch hydrolysis zone as compared to wild strain. Bacillus cereus was observed to have $(157.45 \mathrm{U} / \mathrm{ml})$ of amylase activity, whereas BCM1 and BCU1 were found to produce $207.84 \mathrm{U} / \mathrm{ml}$ and $196.8 \mathrm{U} / \mathrm{ml}$ of amylase activity respectively. From these studies, we found MNNG as a better mutagenic compound.

Table 1. Microscopic, macroscopic and biochemical properties of bacillus cereus

\begin{tabular}{|c|c|}
\hline \multicolumn{2}{|c|}{ Morphological and biochemical characteristics of Bacillus cereus } \\
\hline Characteristics & Results \\
\hline Gram stain & Positive \\
\hline Shape & Bacilli, rods \\
\hline Sporulation & Positive \\
\hline Growth in nutrient broth & Flocculent \\
\hline Growth on nutrient agar & Abundant, cream to off-white color \\
\hline Catalase test & Positive with effervescence \\
\hline Starch hydrolysis & Positive \\
\hline Casein hydrolysis & Positive \\
\hline
\end{tabular}


Table 2. Zone of starch hydrolysis shown by MNNG treated cells after 1 and 2 hours of incubation

\begin{tabular}{|c|c|c|}
\hline Incubation time & MNNG conc. $(\mu \mathrm{l})$ & Zone (mm) \\
\hline$\frac{\vdots}{0}$ & $0 \mu \mathrm{l}$ & 15 \\
\hline \multirow{5}{*}{$\stackrel{\Xi}{\Xi}$} & $7 \mu 1$ & 16 \\
\hline & $14 \mu 1$ & 17 \\
\hline & $21 \mu \mathrm{l}$ & 17 \\
\hline & $28 \mu \mathrm{l}$ & 17 \\
\hline & $35 \mu l$ & 17 \\
\hline \multirow{2}{*}{$\frac{\grave{\Xi}}{\text { N }}$} & $7 \mu 1$ & 18 \\
\hline & $14 \mu \mathrm{l}$ & 16 \\
\hline
\end{tabular}

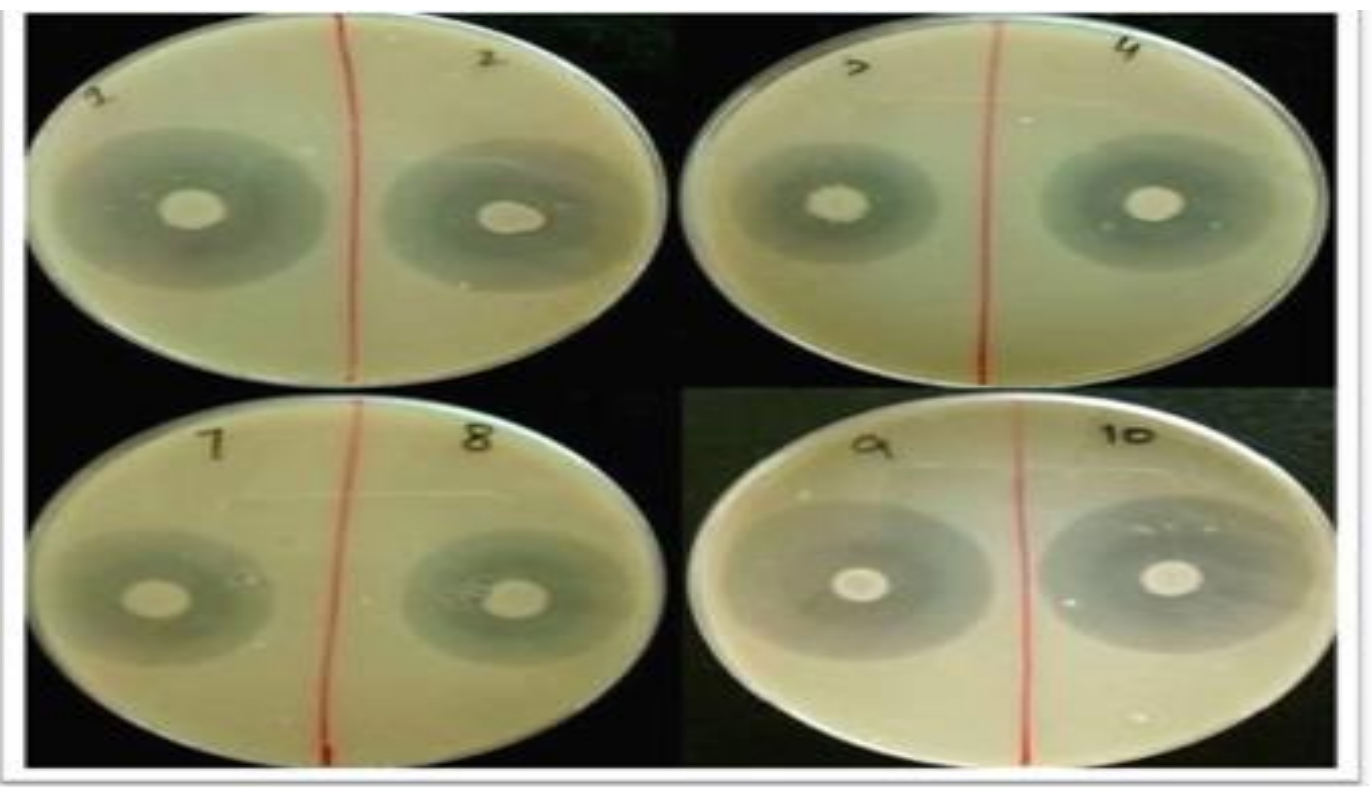

Figure 1. Zone of hydrolysis by selected colonies from 1 and 2 hours treated MNNG culture plates labeled as 1, 2, 3, 4 and 7 shows colonies selected from $1 \mathrm{hr}$ treated culture and plates labeled as 9 and 10 are colonies from 2 hr treated cultures. No: 8 is untreated culture 
Table 3. Data representing the zone of measurement and O.D of UV treated cultures

\begin{tabular}{|c|c|c|c|c|}
\hline & \multirow{2}{*}{ wet mass (g) } & \multirow{2}{*}{ O.D. $(595 \mathrm{~nm})$} & \multicolumn{2}{|c|}{ zone $(\mathbf{m m})$} \\
\hline & & & after $15 \mathrm{hrs}$ & after $24 \mathrm{hrs}$ \\
\hline $0 \mathrm{~min}$ & 0.03 & 0.674 & 13 & 15 \\
\hline $30 \mathrm{~min}$ & 0.05 & 0.691 & 15 & 16 \\
\hline $40 \mathrm{~min}$ & 0.05 & 0.697 & 15 & 16 \\
\hline $50 \mathrm{~min}$ & 0.06 & 0.737 & 15 & 16.5 \\
\hline $60 \mathrm{~min}$ & 0.06 & 0.746 & 15.5 & 16.5 \\
\hline $70 \mathrm{~min}$ & 0.06 & 0.757 & 16 & 17 \\
\hline $80 \min$ & 0.08 & 0.947 & 16 & 18 \\
\hline $90 \mathrm{~min}$ & 0.02 & 0.651 & 12 & 14 \\
\hline
\end{tabular}

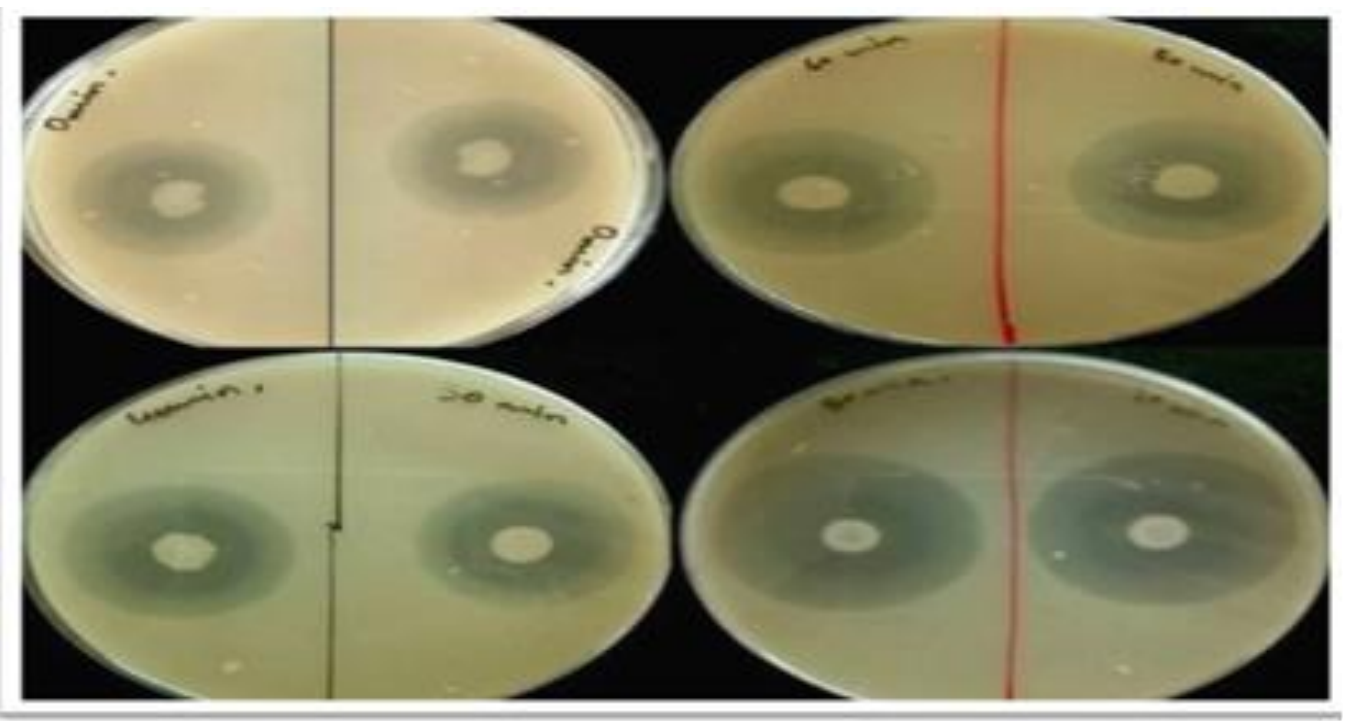

Figure 2. Plates representing zone of hydrolysis after UV treatment from 30 to $90 \mathrm{~min}$ Screening of fermentation media

The choice of an appropriate medium plays a major task in the production of enzymes. Different fermentation media (M1-M5) were evaluated for the production of $\alpha$ amylase by Bacillus cereus A65. Among all used media, $\mathrm{M} 3$ medium comprised of potato peels, $\mathrm{Na}_{2} \mathrm{HPO}_{4}, \mathrm{KH}_{2} \mathrm{PO}_{4}, \mathrm{NaCl}$, and $\mathrm{NH}_{4} \mathrm{Cl}$ gave the highest amylase production (207.84 U/ml), as compared to other media shown in (Table $4 \&$ Figure 3). It may be due to the fact that potatoes are rich in starch. Figure:4 shows the results of SDSPAGE analysis of different fermentation medium with wild, UV and MNNG mutant of Bacillus cereus.

\section{Impact of incubation period}

The effect of time of incubation on the production of alpha amylase was investigated (Figure 5). Fermentation medium was incubated for a total time period of $72 \mathrm{hrs}$ at $37^{\circ} \mathrm{C}$ and culture was drawn after every 12 hrs to determine the time period at which 
amylase production got highest. Results depict that maximum amylase $(207 \mathrm{U} / \mathrm{ml})$ was produced at 48 hours of incubation. After that amylase production decreases. Decrease in activity after a particular time may be due to the reason that media run lack of nutri- ents. It was described by Reese et al. that after a particular time soluble substrate in the medium was completely consumed by microbes and the left over was crystalline portion, due to which the production decreases [30].

Table 4. Alpha amylase activity of Bacillus cereus and its UV and MNNG mutant (BCU1 and BCM1), using different substrates

\begin{tabular}{|c|c|c|c|c|c|}
\hline \multirow{2}{*}{} & \multicolumn{6}{|c|}{ Amylase activity (U/ml/min) } \\
\cline { 2 - 6 } & Apple & Potato & Banana & Rice husk & Wheat bran \\
\hline Wild & 86.4 & 157.45 & 59.78 & 55.2 & 87.5 \\
\hline UV & 92.45 & 196.8 & 110.59 & 59.74 & 92.43 \\
\hline MNNG & 110.4 & 207.84 & 111.32 & 63.21 & 98.70 \\
\hline
\end{tabular}

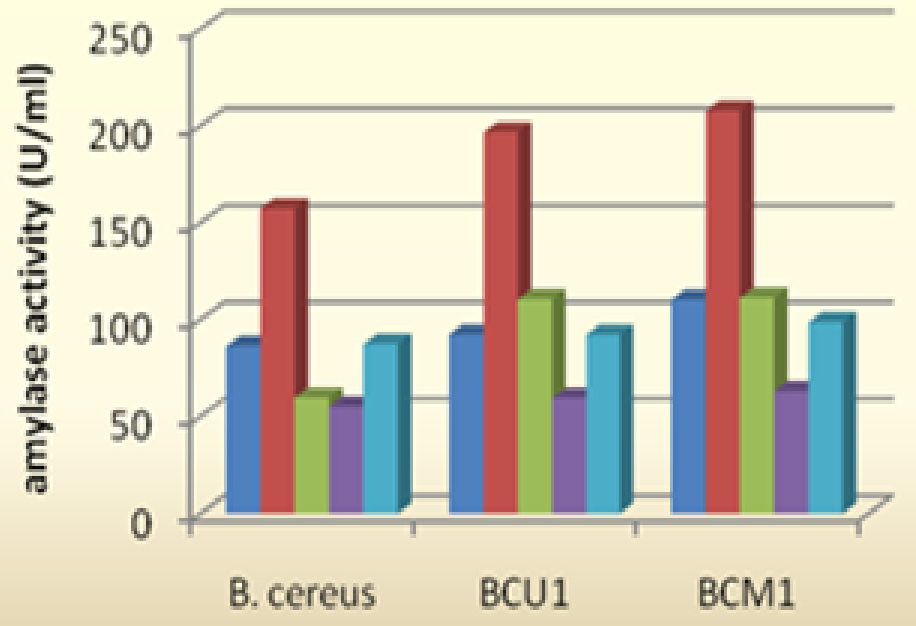

apple peels

motato peels

banana peela

rice husk

wheat bran

Figure 3. Effect of different substrates on wild and mutant strains of Bacillus cereus 

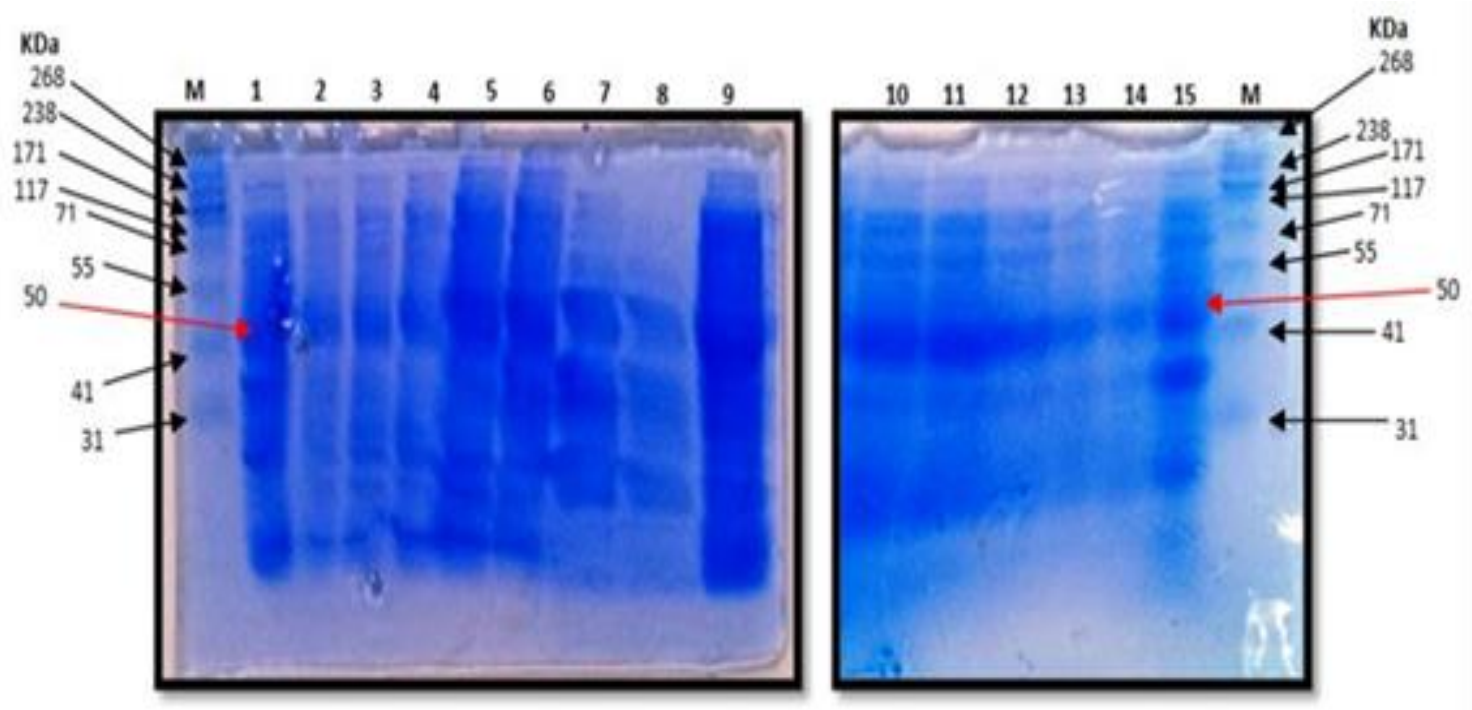

Figure 4. SDS PAGE analysis of different fermentation medium with wild UV and MNNG mutant of Bacillus cereus, Lane $M$ is protein marker; Lane1- M1 media with BCM1; Lane2- M1 media with BCU1;Lane3- M1 media with wild Bacillus cereus; Lane 4- M2 media with wild Bacillus cereus; Lane 5-M2 media with BCM1; Lane 6- M2 media with BCU1; Lane7- M3 media with UV mutant; Lane 8- M3 media with wild Bacillus cereus; Lane 9- M3 media with MNNG mutant; Lane10-M5 media with MNNG mutant; Lane 11M5 media with UV mutant; Lane 12-M5 media with wild Bacillus cereus; Lane 13-M4 media with wild Bacillus cereus; Lane 14-M4 media with UV mutant; Lane 15- M4 media with MNNG mutant

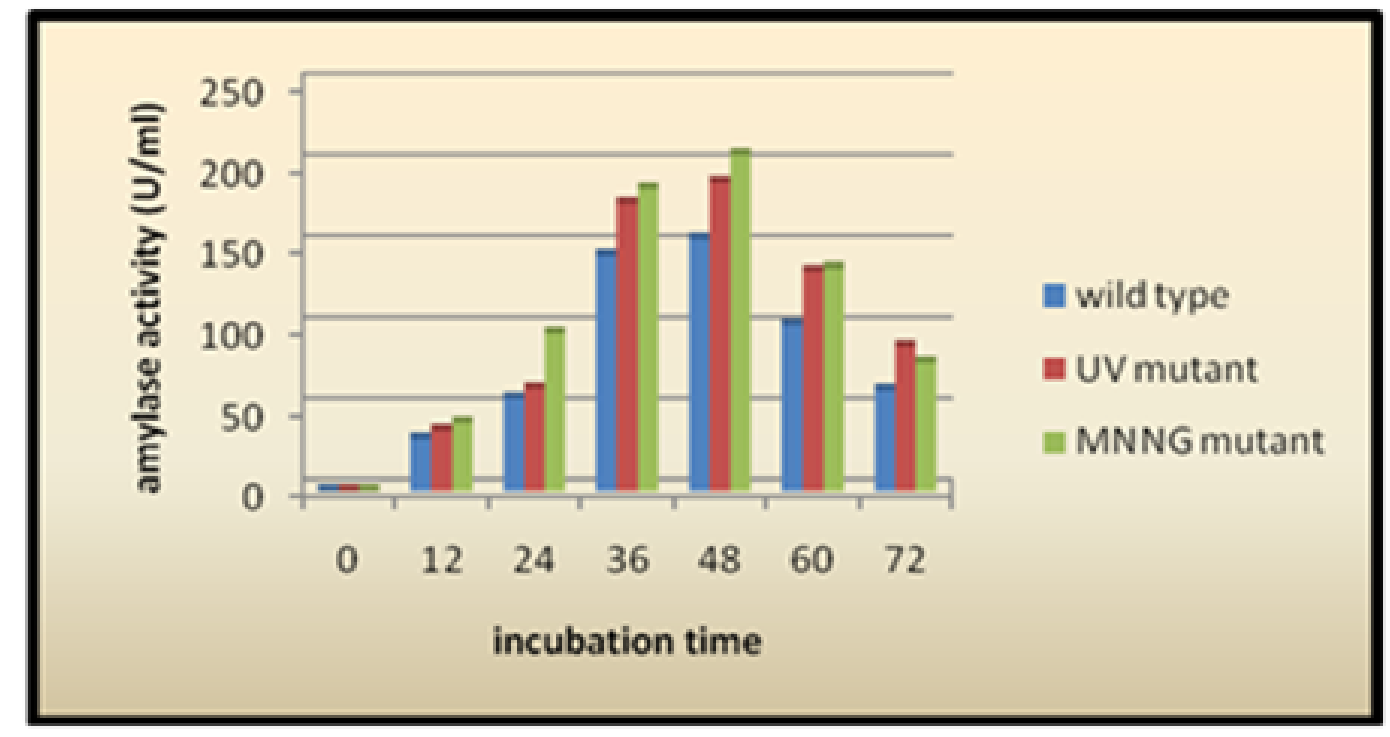

Figure 5. Effect of duration of incubation on amylase activity 


\section{Effect of incubation temperature}

Temperature is one of the most important factors which not only maintains the microbial growth but also affects the enzyme production. In the current research, the effect of incubation at different temperature (17$57^{\circ} \mathrm{C}$ ) was investigated (Figure 6).Maximum amylase production was obtained as 210 $\mathrm{U} / \mathrm{ml}$, during the incubation at $37^{\circ} \mathrm{C}$. Our results matched with Raul et al. who also reported maximum $\alpha$-amylase production at $37^{\circ} \mathrm{C}$ for $48 \mathrm{~h}$ of incubation [31]. At high incubation temperature enzyme production decreases mainly due to the fact that bacterial growth got suppressed due to elevated temperature, and finally, inhibit enzyme production [32].

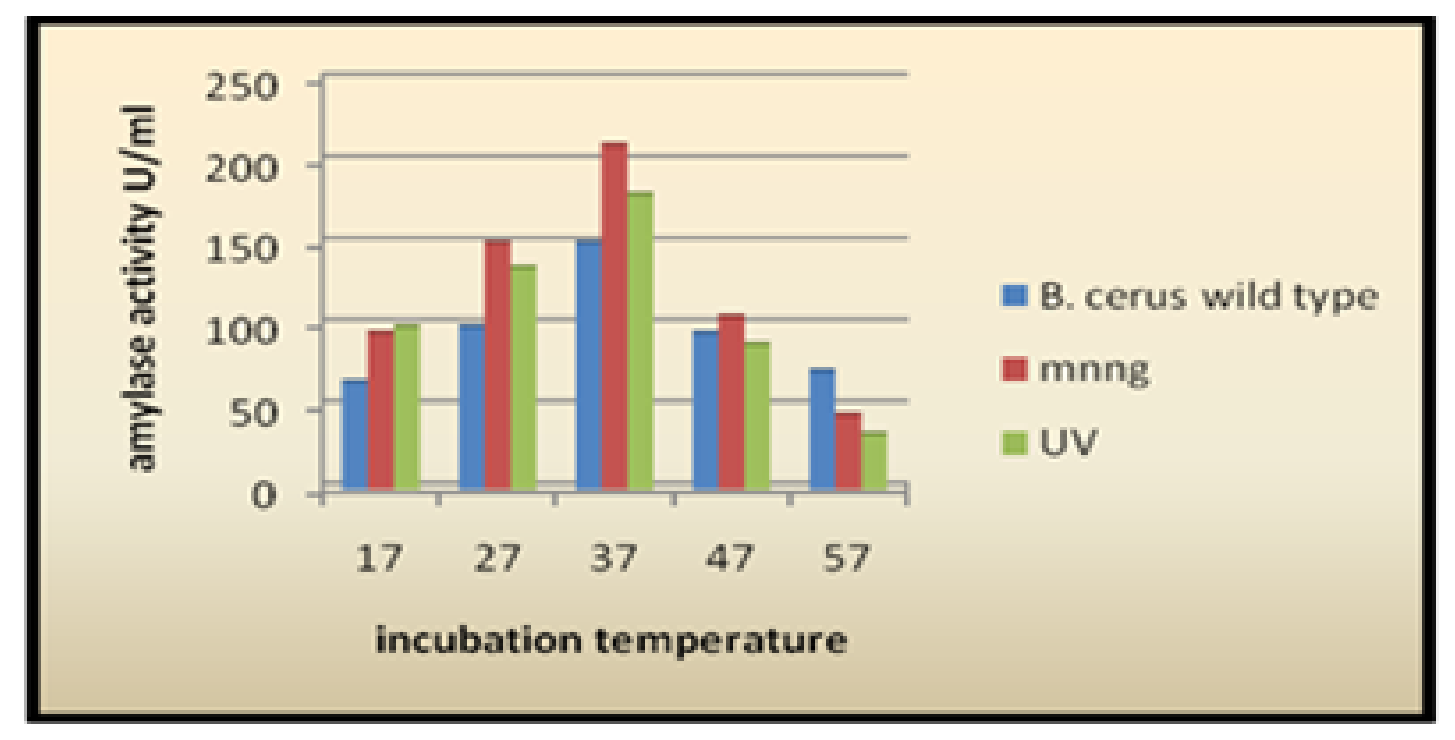

Figure 6. Effect of incubation temperature on amylase production

\section{Effect of $\mathrm{pH}$ of fermentation medium}

During culturing process $\mathrm{pH}$ of culturing medium is one of the most vital parameter because it can bring changes in culture as well as in secretion of enzymes. The influence of different $\mathrm{pH}(5-10)$ on the biosynthesis of amylase was studied (Figure 7). The maximum amylase production (205.4 $\mathrm{U} / \mathrm{ml}$ ) was observed at $\mathrm{pH} 7$. These results are identical with Pavithra et al who reported that the enhanced activity of alpha amylase was observed at $\mathrm{pH} 7.0$ [33]. At high $\mathrm{pH}$ enzyme production decreases because due to the high concentration of hydrogen ions in the bacterial cell growth suppresses which results in the decrease of enzyme production [34]. 


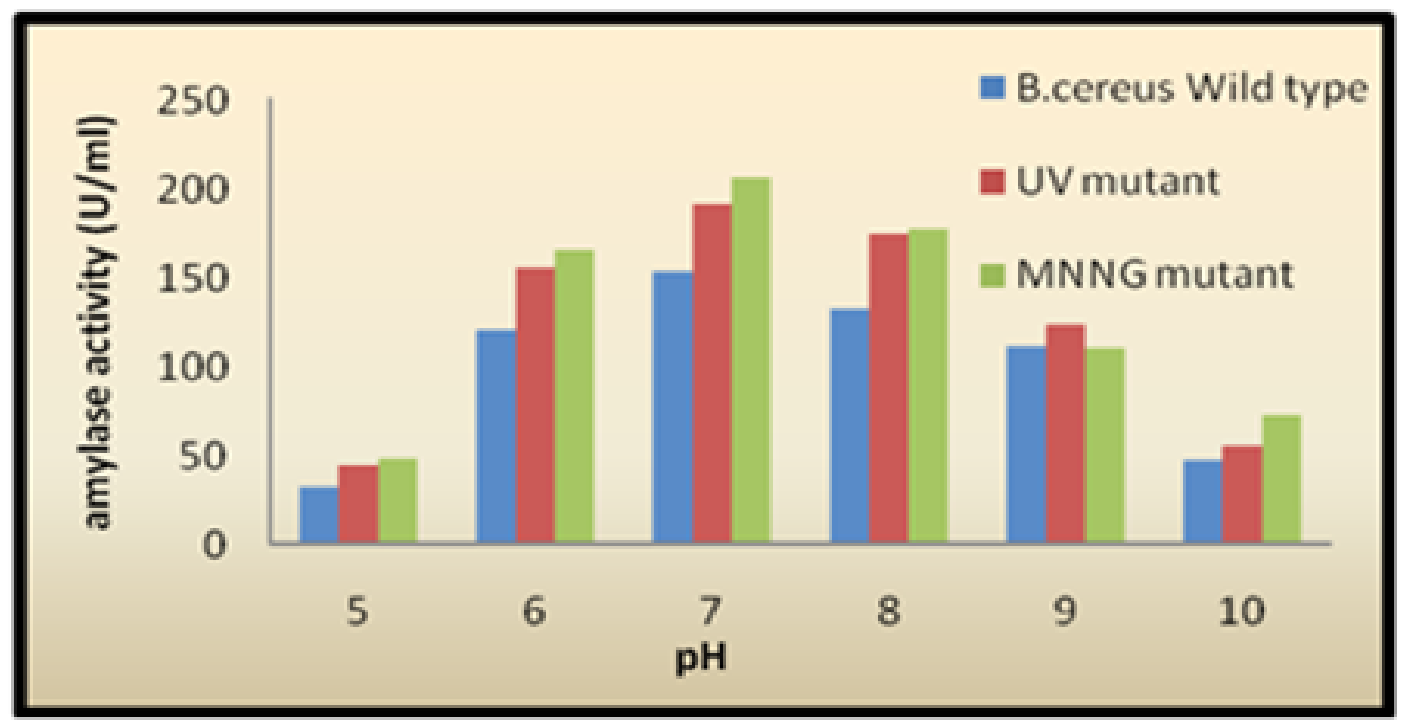

Figure 7. Effect of $\mathrm{pH}$ on production of alpha amylase

\section{Conclusion}

The present study suggests Bacillus cereus as a promising and economical organism for industrial utilization in the field of alpha amylase production. However, studies should be conducted to extract enzymes from thermophiles by using different genetic engineering techniques because amylase used in industrial process should be temperature stable. Moreover, scale-up studies are also needed for the establishment of a cost-effective bioprocess for commercial utilization of this organism for alpha amylase production.

\section{Authors' contributions}

Conceived and design the experiments: $\mathrm{H}$ Bashir \& A Sumrin, Performed the experiments: I Ramzan, Analyzed the data: H Bashir, M Bilal \& I Ramzan, Contributed reagents/material /analysis tools: M Bilal \& A Chaudhry, Wrote the paper: I Ramzan, $\mathrm{H}$ Bashir \& A Chaudhry.

\section{References}

1. Nigam P \& Singh D (1995). Enzyme and microbial systems involved in starch processing. Enzyme Microb Tech 17(9): 770-778.
2. Reddy N, Nimmagadda A \& Rao KS (2003). An overview of the microbial $\alpha$ amylase family. Afr J Biotechnol 2(12): 645-648.

3. Sundarram A \& Murthy TPK (2014). $\alpha$ amylase production and applications: a review. J of Appl \& Environ Microbiol 2(4): 166-175.

4. Souza PMD (2010). Application of microbial $\alpha$-amylase in industry-A review. Braz J Microbiol 41(4): 850861.

5. Srivastava R \& Baruah J (1986). Culture conditions for production of thermostable amylase by Bacillus stearothermophilus. Appl Enviro Microb 52(1): 179-184.

6. Liu YH, Lu FP, Li Y, Yin XB, Wang Y \& Gao C (2008). Characterisation of mutagenised acid-resistant alphaamylase expressed in Bacillus subtilis WB600. Appl Microbiol Biot 78(1): 8594.

7. Liu YH, Lu FP, Li Y, Wang JI \& Gao C (2008). Acid stabilization of Bacillus licheniformis alpha amylase through introduction of mutations. Appl Microbiol Biot 80(5): 795-803. 
8. Deb P, Talukdar SA, Mohsina K, Sarker PK \& Sayem SA (2013). Production and partial characterization of extracellular amylase enzyme from Bacillus amyloliquefaciens P-001. Springer Plus 2(1): 1.

9. Soni SK, Goyal N, Gupta JK \& Soni R (2012). Enhanced production of $\alpha$-amylase from Bacillus subtilis subsp. spizizenii in solid state fermentation by response surface methodology and its evaluation in the hydrolysis of raw potato starch. Starch Starke 64(1): 6477.

10. Saxena R \& Singh R (2011). Amylase production by solid-state fermentation of agro industrial wastes using Bacillus sp. Braz J Microbiol 42(4): 1334-1342.

11. Van Dijl J \& Hecker M (2013). Bacillus subtilis: from soil bacterium to supersecreting cell factory. Microb Cell Fact 12(1): 1.

12. Yoneda Y \& Maruo B (1975). Mutation of Bacillus subtilis causing hyperproduction of alpha-amylase and protease, and its synergistic effect. $J$ Bacteriol 124(1): 48-54.

13. Chi MC, Chen YH, Wu TJ, Lo HF \& Lin LL (2010). Engineering of a truncated $\alpha$-amylase of Bacillus sp. strain TS-23 for the simultaneous improvement of thermal and oxidative stabilities. J Biosci and Bioeng 109(6): 531-538.

14. Niu D, Zuo Z, Shi GY \& Wang ZX (2009). High yield recombinant thermostable $\alpha$ amylase production using an improved Bacillus licheniformis system. Microb Cell Fact 8(1): 1.

15. Singhania RR, Patel AK, Soccol CR \& Pandey A (2009). Recent advances in solid state fermentation. Biochem Eng $J$ 44(1): 13-18.

16. Murthy PS, Madhava Naidu M \& Srinivas P (2009). Production of $\alpha$-amylase under solid-state fermentation utilizing coffee waste. $J$ Chem Technol Biot 84(8): 1246-1249.

17. Demirkan E, Sevgi $T$ \& Başkurt $M$ (2017). Optimization of physical factors affecting the production of the $\alpha$ amylase from a newly isolated Bacillus sp. M10 strain. Karaelmas Fen ve Mühendislik Dergisi 7(1): 23-30.

18. Kaur A, Kaur M, Samyal ML \& Ahmed $\mathrm{Z}$ (2017). Isolation, characterization and identification of bacterial strain producing amylase. $J$ of Microbiol and Biotechnol Res 2(4): 573-579.

19. Mishra S \& Behera N (2008). Amylase activity of a starch degrading bacteria isolated from soil receiving kitchen wastes. Afr J Biotechnol 7(18).

20. Garrity GM, Bell JA \& Lilburn TG (2004). Taxonomic outline of the prokaryotes. Bergey's manual of systematic bacteriology. Springer, New York, Berlin, Heidelberg.

21. Sambrook J (2001). Molecular cloning: a laboratory manual/Joseph Sambrook, David W. Russell: Cold Spring Harbor, NY: Cold Spring Harbor Laboratory.

22. Saito H \& Miura KI (1963). Preparation of transforming deoxyribonucleic acid by phenol treatment. Biochim et Biophysica Acta (BBA)-Specialized Section on Nucleic Acids and Related Subjects 72: 619-629.

23. Wilson K (1987). Preparation of genomic DNA from bacteria. Current Protocols in Mole Biol 2.4. 1-2.4. 5.

24. Gibson T \& Gordon R (1974). Genus I. Bacillus. Bergey's manual of determinative bacteriology, 8th ed. The Williams \& Wilkins Co., Baltimore 529550.

25. Mao Z, Yu C \& Xin L (2015). Enhancement of Phenol Biodegradation by Pseudochrobactrum sp. through Ultraviolet-Induced Mutation. Inter $J$ Mol Sci 16(4): 7320-7333. 
26. Kim $\mathrm{CH}$, Sata $\mathrm{H}$, Taniguchi $\mathrm{H}$ \& Maruyama Y (1990). Cloning and expression of raw-starch-digesting $\alpha$-amylase gene from Bacillus circulans F-2 in Escherichia coli. Biochim et Biophysica Acta (BBA)-Gene Structure and Expression 1048(2-3): 223-230.

27. Huang CJ, Wang TK, Chung SC \& Chen CY (2005). Identification of an antifungal chitinase from a potential biocontrol agent, Bacillus cereus 28-9. BMB Reports 38(1): 82-88.

28. Anto H, Trivedi U \& Patel K (2006). $\alpha$ Amylase production by Bacillus cereus MTCC 130 using solid-state fermentation. Food Technol and Biotech 44(2): 241-245.

29. Mobini-Dehkordi M, Jafari-Dehkordi S $\&$ Saffar B (2017). Characterization and increment of amylase production in mutant strains of Iranian native Bacillus licheniformis. Biological $J$ of Microorg 6(21): 67-81.

30. Reese E, Lola J \& Parrish F (1969). Modified substrates and modified products as inducers of carbohydrases. $J$ Bacteriol 100(3): 1151-1154.

31. Raul D, Biswas T, Mukhopadhyay S, Kumar Das S \& Gupta S (2014). Production and partial purification of alpha amylase from Bacillus subtilis (MTCC 121) using solid state fermentation. Biochem Res Inter 2014.

32. Nusrat A \& Rahman SR (2007). Comparative studies on the production of extracellular $\alpha$-amylase by three mesophilic Bacillus isolates. Bangla $J$ of Microbiol 24(2): 129-132.

33. Pavithra S, Ramesh R, Aarthy M, Ayyadurai N, Gowthaman MK \& Kamini NR (2014). Starchy substrates for production and characterization of Bacillus subtilis amylase and its efficacy in detergent and breadmaking formulations. Starch Starke 66(11-12): 976-984.

34. Gupta A, Gupta V, Modi D \& Yadava L (2008). Production and characterization of $\alpha$-amylase from Aspergillus niger. Biotechnol 7(3): 551-556. 